\title{
Death, Desire, and the Generation of Metaphor
}

The metaphoric account of death is constructed in terms of transition and travel, another metaphor. But then, all metaphors travel. Just like in the case of desire, the originally metonymic idea turns into a metaphoric one once its transitionary and transcendental nature is developed in full. Desire, understood as a metonym, becomes a metaphor when it travels along the same path that any metaphoric construction must use, from this world to another desirable possible world, from one realm of discourse to another. Ultimately, my desires are flights of fancy and they blend in with wish-fulfilment, just like the ideas of death do. The point is, therefore, that a metaphor itself is a process that is characterised by a meaning moving over to another field of discourse. In this sense, death, desire, and metaphor exhibit a dynamic isomorphic structure: death takes one from here to eternity, desire aims at a novel desirable possible world, and every metaphor evokes a fresh field of discourse beyond the limits of the ordinary.

\section{Prelude: Death and Dress}

Tom Paine, in his once so famous pamphlet Common Sense, makes a brave literary effort in terms of figurative language when he writes, ${ }^{1}$

Government, like dress, is the badge of lost innocence.

What he means is that society may be good for people, or a blessing, however troublesome social life may sometimes be, but government, the seat of coercive power, is nothing but a "necessary evil."2 It is our own fault that we do not manage to preserve the sphere of social life intact but need the weapons of violence implemented by the state and its elites to guarantee our life and limb: this is what he means by "lost innocence." The government threatens us and we listen. We all wear that badge when and because we succumb to the power of the government as a purveyor of violent death and serfdom. Indeed, government associates both with safety and violent death, which is not far from what Paine intends to say. Government is the agent of death both literally and

1 T. Paine, Common Sense. London: Penguin Classics, 1776/1986, p. 65.

2 Ibid.

(C) KONINKLIJKE BRILL NV, LEIDEN, 2019 | DOI:10.1163/9789004410305_007

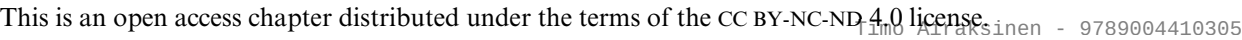


metonymically (wars, death penalty) and metaphorically (the law as a sword, mortal god). ${ }^{3}$ However, how he says it is more important than what he says.

Let us first modify his original aphorism thus,

Death, like dress, is the badge of lost innocence.

What is then the true paradigm case of the badge of lost innocence, or death? It must be the Biblical event of Eve offering Adam the forbidden fruit of the Tree of Knowledge. They ate it and then saw their nudity in dire need of clothing to cover their shame, which indeed entails the loss of innocence. ${ }^{4}$ Their shame, masked with clothing as scant as a fig leave, was accompanied first by fearful doom of labour and death and then by death itself. Of course, whatever they do or wear they cannot hide their crime and hence die they must, first metaphorically and then literally. They try to hide their crime with a badge of lost innocence, which is nothing but an oxymoron - to hide is to announce. Their dress reveals their crime. Now the man and wife are metaphorically dead - they have lost their life - although they still walk about and out of the Garden of Eden and live a long, productive life afterwards.

Paine's contemporary audiences knew full well what that paradigmatic case of "lost innocence" is: sin and death in Paradise. It is not like death, one should not exploit such a simple simile where a metaphor is clearly needed. Government is the badge of death as the fruit of crime, a cause of lost innocence that must be camouflaged as quickly as possible by a dress - another metaphor appears here. For example Hobbes and Hegel both agree that all governments are initially based on violence and conquest, even crime, so that Paine just follows a long-lasting tradition here. ${ }^{5}$ Hence, if death is the original badge of lost innocence, then it follows that Government is death, or death of freedom and individuality. This is easy to see via a simple substitution of "death" for "badge of lost innocence":

Government, like a dress, is death (of innocence), or Dress is death.

3 T. Hobbes, Leviathan, 1651: "laws are of no power to protect them, without a sword" (Ch. 21). The sword is Hobbes's recurring metaphor.

4 For instance, Adam in John Milton's Paradise Lost (1674) says about Eve: “Defaced, deflow'red, and now to death devoted? / Rather how hast though yielded to transgress" (Book IX, 901-902).

5 Hobbes: "Conquest, is not the victory itself; but the acquisition by victory, of a right, over the persons of men." (Leviathan, Review, and Conclusion). G.W.F. Hegel: "Heroic coercion is a rightful coercion," when heroes found states in the condition of nature (Philosophy of Right. Tr. T.M. Knox. Oxford: Oxford University Press, 1952, § 93, Addition). Hegel repeats this Hobbesian idea in many places, for instance, $\S \S 102,167,35^{\circ}$. 
Obviously, one can wear death if dress is death and death is dress - all mortals do. As Plato says, all humans live their life under the false pretence that they are alive. ${ }^{6}$ What we normally call life is bodily life but everything that is dependent on the body is an illusion. It follows that life is an illusion and the body death, or body is the badge of death, or a dress. In this sense, body is what dies. In other words, independently of its illusory temporal contingencies a body is dead. Real life is elsewhere.

The key metaphor, namely, a dress is "the badge of lost innocence," is how Paine puts it. Then death is a badge or dress, something that tells us a story, and not a state of affairs. No dress fails to tell a story, which is to say that dress/death is a metaphor. We can call this a transitional metaphor that mediates between a terrible crime, or our lost innocence, and the consequent shame and death. Dress covers our shame, our sex that is; death shields our lost innocence and this is its sole function in this literary context. When Paine says that the dress covers us as a badge, is it the badge that covers and not the dress? Although we know that a badge, in its metonymic sense, covers nothing as it just indicates the right direction of thought and perception by labelling something that needs a label to indicate how to take it. It reveals what there is. Hence, a badge covers nothing but that very fact makes the dress look like something that labels, directs, and reveals. "A dress as a badge" is a strange metaphor, because a dress that does not cover is not a dress. At the metonymic level this indicates a paradox, which is easily resolved through its metaphorization. Now a dress covers (metonym) but it also reveals (metaphor) when it is used as a badge that reveals. A dress can be a badge but a badge cannot be a dress. When you wear your dress you tell your story. When you wear a badge you remain naked.

Now, death is the strangest of badges, why? Because death as a metaphor first hides and then, as a dress, covers it all and hence moves one across the boundaries of discourse to somewhere unimaginable, that is to the Promised Land. In other words, metaphor moves the thought via a transition towards transcendence; this is what metaphor does just like death itself does as a metaphor. Let me explain. A metaphor always is about distant and strange realms of meaning, just like death is about the faraway lands where we travel when we die. A badge attempts the same, namely, it tells us to move across the fixed boundaries of this world. Think of a badge of honour: it invites us to move over to the dream world of the ideals of virtue, honour, and heroism. The badge is then no longer a mere label that indicates what there is and what to think of its carrier; on the contrary, it is now a badge that refers outside of itself, like a medal of honour that refers to some distant battlefields or the red badge of

6 See Plato, Republic, 514a-520a: The real life is outside of the Cave. 
courage that moves its bearer to a world of imagination and fiction. Think of a yellow star: it is a badge that directs deranged thought to fictional crimes that necessitates both shame and the dress/badge. A dress code, therefore, refers to the iconic cult of dressing prim and proper, or fancy and lavish; it is a paradox and parody, as it is easy to see, a vain attempt to forget what a dress is all about - an attempt to write the name of our crime in nice lettering. The proof: your dress must cover your sex. Your dress is then the badge that commemorates the original sin whose reward is death. But you play with and around this truth when you follow a dress code that covers the original purpose of the dress; it is all ironic. The badge refers to death and yet you dress fancifully.

\section{Meaning of Death}

Gerald Doherty writes in his seminal Theorizing Lawrence about death as a metaphor and a metonym. ${ }^{7}$ I agree with him, how could I not, as he makes this detail foundational, namely, the transitional and transcendent nature of death, or the ascending/descending travelling metaphor of death that is so dear to people in the Christian and Muslim cultures, or the Heaven and the Hell in afterlife. For a strict anti-Catholic Buddhist like Doherty himself, such notions must remain totally alien but, yet, they are there to be seen and pondered about. He is not a Pure Land or Field of Merit Buddhist. He believes in Nibana, which is written on his gravestone in Rymättylä, Finland. Let us look at Doherty's seminal ideas.

I already referred to the transitional and dynamic death metaphor: death is a trip either to Heaven or Hell. Also static metaphors can be formulated, although one might argue that they do not make much sense without their transitional counterparts. Think of the old Aristotelian eudaimonistic rule, "No one can be called happy before death" and its Japanese militaristic version, "No man can be called brave before his death." Here death, at its metaphoric level, is the ultimate pinnacle of meaning, the final thanatological truth about the purpose of human life and about its supreme moment of judgement - as Doherty reminds us. A person dies and the true nature and meaning of her life is thus revealed in full at that crucial moment when nothing can be added or taken away as one's life is now complete. Completion is a fitting sub-metaphor

7 G. Doherty, Theorizing Lawrence, Nine Meditations on Tropological Themes. New York: Lang, 1999, pp. $5^{1-56}$. When we call the end of life death we are dealing with a metonymic pair. When we call death the end of everything we introduce a metaphor. Unlike in the metonymic case, we hesitate to say it is true/false. 
here. The same idea can be seen in the Christian idea of Last Judgement where all humans are classified as good or bad by some absolute Celestial Authority. Here they are, beyond time and place, all souls, naked and bare, without dress, so that their careers can be seen at a glance and judged accordingly - such is the positive but static metaphor of death. The problem of this static metaphor is that it is impersonal: the static metaphors of death are different from the dynamic metaphors of personal death and dying. Death is the completion of life, we said, but where is then the person? All death assumes a person. Now she is no longer there so that we need as if to deny her death and make her travel across some distant lands towards a transcendent goal. Only in this way can we make sense of her death qua personal death. She cannot die, on the contrary, she only moves from here to there. In other words, death is not real when it means a person traveling between worlds; when death is not real it becomes a metaphor of the person's ultimate destiny. The static idea of death as an end loses the person when her transition from here to the goal preserves her. This is because an end is the static stop and the goal where one aims at. What reaches the end disappears; whatever aims at a goal lives on. When a runner reaches the end he no longer is a runner; when he aims at the finishing line he must move on.

This is the starting point of fundamentally dynamic narratives, the essence of which is a vertical metaphor of transition and transcendence. Some of these metaphors are religious but not all. A medic turns to shocked relatives and says, "I am afraid he is gone," which is to say the patient has passed away, not only out but all the way out and away. When you pass out you may still come back unlike in the case where you pass away. Now you are gone and that is to say you are not coming back. This is a simple unidirectional and horizontal transition metaphor that utilizes the idea of some kind of border that you cross and a gate you go through, and that is all - the dead person just vanished from our view but she still is out there somewhere as a traveller. Religions may then utilize much more detailed travel narratives.

The plot thickens when the dead person goes to Purgatory, approaches Heaven, meets its Gate Keeper, reaches the Paradise or the Elysian Fields, the Pure Land, or the Upper Room, and then perhaps meets her Maker. Perhaps she goes to the deepest Hell to suffer there. Obviously, the dead person is not really dead; on the contrary, their death is a badge of his rebirth and a rite of passage that opens up the gateway to something that is so much bigger and better beyond all time and place. This is the land of salvation, purity, eternal happiness and ever-lasting glory, or the new life of pure joy, adulation, devotion, harps, and white dresses under angelic wings. In this way death paradoxically turns itself into a firm denial of death in terms of a transcendent narrative that utilizes 
the widest variety of desirable notions, when death turns out the be the gateway into such rich applications of desirable images. The key metaphor here is the gateway and the route of access to the realm of transcendent existence whose purpose is the firm denial of death as a metonym. Here the metonym itself is the enemy to be conquered, if you want to live forever. Death as the end of life sounds intolerable indeed. It is a nasty and demeaning metonymy.

Of course, death must be treated as a metonym, too. It is something that happens to all of us when one's time has arrived. Death is then the end of life as a hard fact, which now exhibits its metonymic garb: death is the moment your life ends, when your key organs stop working, when you draw your last breath, when you kick the bucket, when you give up the ghost, or however you might want to describe this final episode of your life, dying. Notice, incidentally, that such phrases have no metaphoric import; on the contrary, they support the metonymic notion of death. They illustrate the fact that one's life has ended. Now, the metonymic language of death also resists death in its peculiarly stubborn manner, as if we refused to admit the very possibility of death and dying. All this is understandable because death is the final, dark, bottomless abyss and dying the chaotic maelstrom that sucks you in ever so relentlessly, as Edgar Allan Poe so masterly narrates. ${ }^{8}$ Nobody can help you, yet all that lives dreads death and screams for help, when death is treated at the metonymic level of discourse. Only the ascending metaphor of a paradise can relieve your anguish and hence you need and desire it. You aim at it, yet the cruel and depressing metonym is always there for you to think about. I will argue that such a metonym struggles against death while death as metaphor celebrates it by saying that life beyond death is your real life and your earthly wanderings but a shadow of it. You advance from death to life in Heaven - here we have first an ascending and then a vertical metaphor in a true Platonic context.

The metonyms of death wage their endless war against death. Think of this,

George was such a good person. We all miss him so much now when he is deceased and we stand by his grave.

Such a metonymically construed narrative of the dead George can be expanded at will without making it feel too strained or misleading. It simply tells us how things are. George is dead when we stand there, the participants in his burial ritual listening to the stream of positive jargon straight from the priest's liturgy book. However, metonymic language, unlike the metaphors that celebrate death, struggles to admit the key fact, namely, the end of the life of the person.

8 E.A. Poe, "A Descent into the Maelström." In Complete Tales and Poems. New York: Vintage, 1975, pp. 127-170. 
This entails no person. We say, "We miss him," as if he were there to be missed; or, as if there still were somebody called George around. There is nobody. We stand at his grave; whose grave is it? The proper name no longer refers because George fails to exist. Yet we still treat George as an existing personal entity when we use this proper name. What we should have said is, "We miss what used to be George," or "We stand by the grave of a corpse that, when he was a living person, was named George." ${ }^{9}$ But how could we love a corpse? Nobody misses a cadaver; one misses a person.

It is impossible to miss the person who does not exist - there is nobody to miss - and a proper name fails to make sense when the referent simply is no longer there. It is all fictional. Such a fake manner of treating metonymic death is not just a matter of linguistic convenience, as it might be, but a matter of deep metaphysical fear. The metonymic treatment of death is intolerably cruel and painful to us. Hence, we need to escape to the more tender realms of ascending positive metaphors. Sometimes we do not go along that route, for instance, when we actually stand by George's grave and remember him ever so sweetly. Alas, the cruel fact is that this is not George's grave, and thus there is nobody to remember, sweetly or not, must be intolerable to the living; hence, we must modify our metonymic language of death accordingly. We keep George alive by our linguistic conventions, which obviously consoles us enough to make the idea of death somehow tolerable. Alternatively, such metonymic games provide us an opportunity to make the crucial leap to the happy lands of transcendent metaphors, or Hic Rhodus, hic salta:

We now stand by George's grave but we honestly believe that He himself is knocking at the Gates of Heaven and entering the Upper Room where we will meet Him. When our own time is up we are ready to follow George and to give up this Vale of Tears in order to start living anew.

The parallel incongruities of the metonymic and metaphoric accounts are as obvious as they are revealing. First, we say (metonymically) that George lies dead in his grave here and now but then we continue to talk as if he still were present. Second, we say that our dear dead George is now alive somewhere else, that is, in Heaven (metaphorically). Ever so paradoxically, George is now in his grave and also in Heaven, in other words in two different places at the same time. Such contradictions do not sound so bad if both the metonymic and

9 K. Burke, in his The Rhetoric of Religion (Berkeley: University of California Press, 1961) explains this phenomenon as follows: it is the "personal name that can be said to survive the physical death of a particular person who bore it." (p. 209). A person's name is a talisman that keeps the person alive for us. This is the thesis I try to argue for above. 
metaphoric language tell us the same story: George is still somehow around first here and then there as well. The metonymic language struggles and threatens to break down due its grammar but metaphors reign free and as supreme as ever. Hence, the Land of the Dead is ruled by metaphors that are immune to such paradoxes. Ultimately our metaphors must win or otherwise we could not face death. We may try to manage by using a metonym: "This is George's grave," and thus deny the death of George. But we know this is false. We need a metaphor even if we may not use the full travel story from here to eternity. A minimal metaphor may well suffice: "George is gone." This is enough to expel the truth that no George exists, just a rotting body in a cold grave. At the full blown rhetorical level, death is a mixed metaphor: at the same time static and dynamic, good and bad, ascending and descending account of life outside all life - it is a notion that is rich in content but always in denial of itself. ${ }^{10}$

\section{Meaning of Desire}

Tropologically speaking, desire is a transitive and transitionary notion, just like death, and it, like death, helps us understand metaphor and metaphorization. One of our very basic desires is, anyway, the desire not to die. Two sorts of desire are relevant here: (mere) wish-fulfilment and (true) want; I also call them wishes and desires because not much hinges on such a choice of words adopted from the morasses of folk-psychology. Of course, wish-fulfilment is a Freudian term but, again, not much depends on this historical detail."

Notice that a wish is self-satisfying: what you wish you also get just by wishing for it; this is called wish-fulfilment. This is different from longing for something you know you do not have and cannot get. Actually, the object of a wish and longing may be the same, just the attitude is different. When I wish to be young again, I feel I am young; when I long for my youth I know I will never get it back. For this reason one can speak of wish-fulfilment even if you never fulfil your longings. Wishes are sweet and longings bitter. Wish-fulfilment is conditional only on the properly developed wish itself and its narrative content. Desires are not so easy to satisfy: their satisfaction depends on something that

10 I have benefited from K. Burke's Appendix D: Four Master Tropes, in his seminal A Grammar of Motives (Berkeley: University of California Press, 1969). I regret I cannot deal with the ironic aspects of the topics I focus on in this short paper. Most of them suggest a dialectic reading, which indicates irony; also Doherty, 1999, p. 55 .

11 See for instance T. Pataki, Wish-fulfilment in Philosophy and Psychoanalysis. London: Routledge, 2014 . 
is outside of the desire itself, or their de re object. Therefore, desire as want is different from a wish. ${ }^{12}$ Suppose I want to be a decent person and good father. What I want is a new possible world where I am a decent person and a good father, that is, a world that is otherwise similar to this actual world where I am what I am now. In other words, I want something that satisfies my desire and hence gratifies me personally, a world where I am a better person than I actually am here and now. More specifically, what I want is to transit to that world; hence, desire is a transitionary idea. Notice, and this is important, that the differences between the new possible world and my actual world is dictated by my desire, otherwise no satisfaction of desire may emerge. This is of course unrealistic: the new world where I am a good father must have many non-intended features as well. My wife may not like me anymore and my friends may change as well. We can take this into account by means of the standard distinction between de dicto (what I nominally mean concerning my want) and de re desire (what I actually get as the object of my want). De dicto I want the world where I am good and no other changes; de re I get a world that has changed much more than that. Notice also that de dicto desire entails, as above, a narrative account of the intentional object and goal of desire. Hence, to make sense of my current desire I must narrate my account of good fatherhood and decent personhood so that they make sense to me and my intended audiences.

The same is true also of such trivial desires as I want ice-cream. Ice-cream is not desirable as such - even if some people like it - hence I need to tell more about it so that it starts looking desirable to me. I say, I always eat ice-cream when the sun shines, which reminds me of my late dear father who always bought me some. Of course, certain objects of desire are desirable as such. If I say I do not desire good life, a special explanation is needed. Also notice the difference between wish-fulfilment and desire here: I desire that I go and get ice-cream unlike in the case of a wish when some imaginary substitute may do the work for me. For example, I look at children in the park enjoying their icecream, I mentally re-live my childhood, and that is that - I wish I could be like them. It is like the difference between being in the audience of a boxing match or climbing into the ring wearing boxing shorts and donning a pair of gloves. One more basic point is crucial concerning desire: what I want and what I get always are two different things. Strictly speaking, I never get what I want: I want to relive my childhood summers but whatever I do or get will not bring them back. I may want ice-cream and get some ice-cream, but I did not want

12 See T. Airaksinen, "Desire and Happiness," Homo Oeconomicus 29 (2012), 393-412; and "Narratives of Desire." In Desire, T. Airaksinen and W. Gasparski (Eds.). New Brunswick, NJ: Transaction, 2016, pp. 3-58. 
just ice-cream but so much more, and this is to say I did not get what I wanted. Of course it is not necessary to be so strict because you also may adopt a more moderate approach: if you get something somehow comparable with the de dicto object of your desire you may call it satisfaction. We learn to be flexible and modest with our desires in order to avoid disappointment.

Now, wishes are describable as metonymies unlike desires that combine metonymy with what I call the two directions of metaphor, one trivial and occasional and the other essential and necessary. Let me start from wish-fulfilment. I wish to be a logician and I visited the mathematics library to fulfil my wish there where I, in my mind, miraculously transform myself from a philosophy professor into a logician. This change can be described at the level of metonymy because both terms philosophy professor and logician indicate the same person; this philosophy professor is a logician in my new wish-defined world. It is a metonymic pair. My two personal characterizations are here mutually compatible although this need not be the case. I know I am not a brave person but when I watch war films I am a brave hero, which is fine. But I may wish to be a soaring eagle in the sky, which is impossible, or I imagine I am immortal. All such cases display metonymic pairs.

Jacques Lacan says all desires are metonyms, which may be true but not unconditionally, because desires have their metaphoric elements as well. Let us begin from their metonymic aspects. Look at the following example: I want you to love me and I expect to find a proof of that. Now, your love - first as I want it and then as I get it, if I get it - includes two different things that are related in metonymic terms. As I see it, this is Lacan's point. ${ }^{13}$ There is a pseudo-temporal gap as all gratifications are deferred: I want your love and I get it later; what I already have I cannot desire. Hence, what I get is never the same thing that I wanted. Of course, such a pseudo-temporal argument is figurative meaning simply that the de re object is different from the de dicto object. What happens is that I, ambiguously, want both as if they were the one and the same object, which would guarantee desire satisfaction and my gratification. Such an ambiguation is a practical blessing as it allows you to keep up the illusion that you in fact are gratified - though it is an illusion. Once you notice the nature of this ambiguity you also will see the metonymic language at work: your quest for ice-cream specifies an object that is not the ice-cream in your hand. You probably believe it is because you protect yourself by introducing the relevant ambiguity, which is based on the metonymic relation between the two different intentional objects, objects understood as de dicto and de re, as

13 See D. Evans, An Introductory Dictionary of Lacanian Psychoanalysis. London: Routledge, 1996, p. 38; and A. Lemaire, Jacques Lacan. Tr. D. Makey. London: Routledge, 1970, pp. 195ff. 
ice-cream as you think of it and as you may find it after getting it. Both are present to you in the given situation so that you may freely pay attention to the one or the other without making any changes into the actual world or introducing any alternate possible worlds. You have both objects at the same time so that it does not really matter if they are mutually different. This is how the metonymic language of desire works to save your day. ${ }^{14}$

This is just a beginning because desire has its twin metaphoric aspect as well, as I said above. Trivially, I want to be a stud, where stud is a conventional metaphor for a sexually active male. Such a metaphor is easy to rewrite in metonymic terms: I want to be a ladies' man, or perhaps I want to be admired as such, or I want to compensate for my earlier disappointments. Whatever we say the original metaphor disappears. Of course, in some cases such a linguistic reduction is tricky. When you say men are dirty pigs, what are you saying? What do you want to say? Such metaphors pack an overdose of meaning.

The second type of metaphor is a deeper one. As I see it, a metaphor always travels through the fields of discourse in an unpredictable manner when its purpose is to impress and perhaps stun the reader by revealing something new. A metaphor is meaning in transition so that its import is ultimately transcendental. It moves over gaps and traps ending up in a realm that transcends conventional linguistic borders, except perhaps one: it must somehow make sense however outlandish it may be. It may try to shake off all sense, yet sense must it make. When I say I want to be a stud I travel to the world of horse breeding but not that of winter tires - and invoke all the images of wild stallions in heat. If men are dirty pigs, we discuss life in pig sty, which does not sound nice. The first metaphor is obviously ascending and the second descending. These two examples are trivial as methodological pointers. The truth is that metaphors travel to distant lands where they celebrate their newly found transcendent semantic liberties. Metaphors and desires work in the same way.

Death as a metaphor evokes a transition through a gate or across a river to the distant Pure Land, Paradise, Upper Room, or Heaven; what then are the truly transcendent realms that desire aims to occupy, or what are those desirable possible worlds where desire comes true and one's personal gratification a fact? To answer it is to admit that desire has its own camouflaged metaphoric aspect, just like death does. Death can be treated metonymically and desire is open to the same kind of treatment but both also evoke a more complex and ultimately more rewarding treatment in terms of metaphors of transience and transcendence.

14 See my "Psychology of Desire and the Pragmatics of Betterment." In Pragmatism and Objectivity, S. Pihlström (Ed.). London: Routledge, 2017, pp. 223-238. 
Desire certainly possesses its own dynamism and, along with it, a metaphoric, transitionary, and transcendental structure - but what about its content? Death has, as a gateway to the better world, its unequivocally metaphoric content; we can then ask whether desire manages as well. The prima facie metaphoric treatment of the object of desire is often trivial, as we saw. However, in the non-trivial transitionary cases desire opens up vistas and conceptual possibilities that certainly compare with the rich metaphoric means of death, such as the last moment of truth that condenses the whole life's career into one fleeting but final perception, as described by Doherty. I may say my best literary projects are now dead; that is, their place is in the Great Waste Basket from where I can never recover them.

Now, the focus of desire, or what we want, travels from here to there, or to another possible word where it finally unravels its true meaning. Here is a narrative example: We are on a lifeboat out on the ocean. We have spent a long time in it, we are thirsty, hungry, sunburnt, afraid, and increasingly desperate and we desire a rescue. It is not implausible to want it yet we can do nothing but sit and pray. Then a ship emerges from behind the horizon and saves us. We want to be able to move from the world where we are helpless into another one where help arrives. How are these two worlds related to each other? They are related metaphorically, of course. In our present example this is not so readily perceivable perhaps, but before going into more complex cases we must deal with the present one - if all desires are metaphoric this one must be so as well.

Obviously, to be saved in this new and still imaginary possible world where a ship appears on the horizon is loaded with symbolic meaning. What happens is that the people must now describe the event of the emerging ship in novel terms. What they do is to rewrite their de dicto narrative account of the object of desire. How the shipwrecked see the event depends on many different things, their psychology, belief systems, religion, culture etc.; however, they must react. Just like the moment of death the moment of desire satisfaction is a transcendent event, which entails the realization of a new possible world as a revelation and game-changer, or as the truth of the matter. The desiring agent now reacts to it in a characteristic manner that is not be without metaphoric elements. The emerging ship is sent by God, it is a miracle, it is an answer to our prayers, it is a solution to all our problems, it is whatever you want to call it except a ship whose legal duty it may be to do something about the lifeboat. That would be a metonymic treatment of the case at the level of de re interpretation of desire. But to say that the ship saves us is to say it is a saviour, which comes very close to Saviour. However, we now discuss the de dicto case, the meaning assigned by those people to their emerging desire satisfaction, 
the rescue. For them all of it is bound to be metaphoric. It was metaphoric all the time as they were waiting for a miracle to happen but now, when the ship is there and the de re desire reactivates, all the metaphors become visible and they force themselves to the speech and vision of the people in need. Such a case is nicely analogous with that of death that we discussed above. The Jaws of Death are now avoided.

Indeed, a less trivial example is the will to live, when we give it a metaphoric treatment and forget the corresponding metonymies of death and dying. I say I do not want to die, which is to say I want to go on living. I tell myself a narrative about the event of my dying, my suffering, my fear, etc. I also imagine how my relatives and friends suffer both mentally and materially when I am no longer there to support them. All this takes place in a new possible world that does not exist yet and which I do not want to exist in the future. In normal conditions, this world is not desirable as such and thus I feel I need to avoid it. But what can I do? I know I must die. I then metaphorize my fate, for instance, in this way: I will pass away; hence I do not die but move on to another realm of existence, which I know is better than the present one. I relate to myself the traditional and conventional narrative about such a transition as travel towards Heaven, which is a complex ascending metaphor, or even an allegory, of my newly found better life beyond what I used to know in this Valley of Tears. I know people around me share the same allegory and so I need not worry about that. In this way, the metaphorization of death by means of the traditional travel narrative works to satisfy my desire not to die. I do not die but I live because I travel towards Heaven - this is what I want. The question whether such a desire is satisfiable is beside the point. Desire may also be wish-fulfilment; as far as it is not, the harsh reality of facts will prove to be disappointing.

I have argued that desire can ultimately be understood in metaphoric terms. In other words, the idea of satisfaction of desire brings back the previously supressed metaphoric content. I have no car but when I get it, I get the missing part of my manhood back. It is a long trip from cars to manhood and that is why we need a metaphor here. When I get the car it is the moment of truth when all the hidden metaphors become visible, or a moment of celebration where nothing will be left hidden. The car emerges under the cover of heavy metaphoric meaningfulness revealing the true nature of the de dicto object of a desire that is a hidden metaphor.

Now, my main point is that the full narrative de dicto object of desire grows more and more metaphoric until its contact with its original field of discourse vanishes, like car that is transformed into something else. Think of what all 
this entails to the realizability of our desires. ${ }^{15}$ How to realize a metaphor in the real world, when the metaphor is ineliminable, unlike in our trivial "I want to be a stud" example? Of course, after eliminating the initial metaphor, you can grow it back by expanding the given object narrative. This is the return of the metaphor.

Now, it seems the foundations of our conative life are metaphoric. When we reach this level, we are at the end of the discourse that also threatens to be the death of discourse. After the full and final metaphors have emerged you have nothing else to say; if you say, you cross the limits of understanding, you stop making sense, you do not communicate, and this is the same as opening the gates to somewhere over there that is like the dark abyss of death, or the veritable hell of idiosyncratic private language no one deciphers. Obviously, this means "hell" as a descending metaphor; however hard I try I cannot lead you back to the heaven of understanding. After the last metaphors a gate opens to the foreign world of non-communication and confusion that is devoid of an alternative. In other worlds, my desires, if they indeed are mine, do no longer communicate. They make social interpersonal sense only as long as they are not private, or as long as they are read mimetically, but then they are lacking as desires. They are now more like desire frames or prototypes I am invited to develop further so that they become my own - and then they gradually lose their interpersonal meaning. Or, we stay at the mimetic level and do as others do, but this is no longer the game of desires we are interested in this paper. ${ }^{16}$ It is just mimesis-coordinated social game, a kind of monotonous ritual performance to the highly syncopated music of the social stage, or a dance to the end of time. True desires, when they are my own, always flirt with the limits of communication; this is because of their metaphoric de dicto content. You always can ask, meaningfully, why should you want it?

15 Pessimist have denied the possibility of satisfying one's desires and hence eudaimonia and ataraxia on that very basis, from Buddhists to Simone Weil; see her Gravity and Grace. Tr. E. Crawford and M. von der Ruhr. London: Routledge, 2002, Ch. "The Impossible." The case of Buddhism is, of course, complicated. Desiring brings about unhappiness, think of the following: "I once asked Soen Roshi, 'Why did you want to become a monk?' 'I so badly wanted to become a monk'. he answered. 'But why?' 'I so badly wanted to become a monk'. His wow was truly profound. The intensity of it was remarkable [...]." (K. Tanahashi and R.S. Chayat, Endless Wow: The Zen Path of Soen Nakagawa. Boston: Shambhala, 1996, p. 17). Soen professes a strong desire but his words are at the same time so ironic that the whole skene reads like a parody. He refuses to tell why, which is to say the object of his de dicto desire is missing. This is impossible, if we discuss a desire. The de re object is monkhood. Consequently, he cannot be disappointed if he is a monk. 


\section{Generating Metaphors}

We have seen that metaphor, death, and desire all share the same structure, that is, they all transfer a rich set of meanings from one field of discourse to another, death from here to eternity and desire from here to some desirable possible worlds. ${ }^{17}$ In this sense, their trajectory is a one way road - the respective meanings travel but they will never return - and, because of this, they are genuinely transcendent. By this I mean that once the meanings have been transferred to the novel fields of discourse, they cannot return back to their original fields. If men are dirty pigs, it does not follow that you may say dirty pigs are men. That does not work. Of course, you can play with this impossibility: standing by a pig sty you say "Look, so many men there," which counts as a rather sophisticated irony without metaphoric content. We see that the case of metaphor is different from that of irony and metonymy. If Alexander's armies conquered the world, it is equally true that Alexander conquered the world. In other words, "Alexander" and "Alexander's armies" (metonym) can be used interchangeably whereas "man" and "dirty pig" (metaphor) cannot. Moreover, in the case of a metaphor, the corresponding sentences are not true/false. The paradigmatic case of transcendence is of course death: no one comes back from Heaven and Hell. Yet the Ancient Greeks, like Pythagoras, Ulysses, and Orpheus, could return from Hades, which makes the foundations of their tales of death and afterlife metonymic: life and death can also be seen as a metonymic pair whose terms are in some cases mutually interchangeable. ${ }^{18}$ The effect is curious: a person in Hades is by definition dead but because he can return he is alive - this idea of the returning dead is an oxymoron and perhaps also ironic. Metaphoric meaning travels so far that they cannot return and the dead soul does the same. The unidirectionality of travel is crucially important here, although the concept of travel should entail the possibility of return. Roads can be travelled in two directions. Therefore, the idea of travel as it exists in metaphor, desire, and death has its typical mysterious aspect.

Desire, when its narrative is developed in full, also travels to a point of no return. When it passes this point the desired object never returns back to its original metonymic parent form. After realizing what a car really means to him, a person can never again consider car as a mere technological industrial product, if it remains as the object of his de dicto desire. When a young man

17 Doherty writes: "Like the death-process to which it corresponds, metaphor posits as fundamental the crossing from one semantic domain to another" (Doherty, 1999, p. 52).

18 See P. Kingsley, Ancient Philosophy, Mystery, and Magic. Oxford: Clarendon Press, 2009, for instance Ch. 10 "Plato and Orpheus." 
finally understands what he desires when he desires the woman of his life, there is no return back to the former normal. Perhaps this is why in our Western Christianity based culture desire is so scary to us. We do a lot of work to supress, deny, avoid, and sublimate our desires. "Desire" is a suspicious and even anxious word, especially sexual desire. This can be understood as follows. Desire means anxiety exactly because of its transcendent nature. Once you meet the deepest metaphoric aspects of our desire you also face and feel its transcendent nature; the first aspect entails unsatisfiability and the second irreversibility. You are tempted into a direction of travel that promises no return. When your desire becomes metaphoric, how could you satisfy it? You remain unhappy, yet you cannot find your way back. You now carry the emblem of lost innocence, like a dress you cannot undress. You have what you have and you cannot give it back regardless of how you think of it. Your world has changed irrevocably. Obviously, the fate of Humpty Dumpty illustrates successful desires.

In this way, death, desire, and generation of metaphor all behave in the same way, only their respective degree of concreteness varies: death is an (simple) event, desire a (complex) mental episode, and metaphor a (useful) linguistic trope; hence, I can desire death as a metaphor. All three share a structural similarity, which seems to entail that we need to draw a distinction between metaphor and meta-metaphor that covers all three diverse cases. In fact, what we normally call a metaphor is actually a meta-metaphor, I mean we can treat metaphor as another metaphor just like we treated death and desire as metaphors, or metaphoric linguistic structures.

Example: The verifiable fact that you are a witch anchors your destiny to the age-old tradition that is delivered to us from the dawn of time. This sentence contains three key metaphors, anchoring, delivering, and dawn of time. The second is a dead metaphor that no longer works as a metaphor. Dawn of time may sound pompous. Anchoring is a better metaphor, although certainly not too fresh or interesting one, but it is a working metaphor anyhow. This is to say that the meaning of the sentence travels from a factual social description to seafaring and its methods of keeping a vessel from moving in current and wind. It is a simple horizontal metaphor that amasses new meanings to the case and solidifies our imagery assuring us of the reality and seriousness of the case that is witchcraft. Think of these metaphors whose target is the former Romanian dictator Mr Ceausescu who was Romania's Hero of Heroes, the Genius of the Carpathians, and the Danube of Thought. These come very close to mixed metaphors. They spread their meaning in diverse directions, like a scattergun of one's own cursed imagination, allowing us to form no unified idea of what is said or intended. Hence, we want to give up dead and mixed metaphors and concentrate on those that travel with us towards some new 
and fresh realms of allusion, thus proving us with new insights on what one's linguistic intentions and imagery might do. Metaphors, when we focus on their creation and construction, are both transitionary and transcendental, or even transitory, just like death and desire metaphors are. It is all about making meanings travel between the realms of discourse, first to Heaven and Hell, then to new possible worlds, and finally anywhere where a meaning can go when the travel is a one way road.

Metaphor is a novel cluster of meanings, true, but I do not mean this basic fact; what I am interested in is how we may construe our metaphors in terms of flight of fancy. The metaphoric process brings about metaphors like those of death and desire; here the metaphoric process is a dynamic frame whose slots take in various ideas and images and turn them into specific metaphors. When you consider death as a metaphor you are bound to travel to distant lands and realms all the way to Heaven and Hell from where no one ever came back - this is what the metaphor-generating process does to us. An abstract truth, death, gets its concrete formulations in terms of Heaven and Hell, or the reification of the place where the metaphoric process will necessarily take you anyway. There is no metaphor without transition and travel of meaning that now admit its concretization in terms of the Land of the Dead on the other side of the River Styx or, if you like, the Gates of Paradise watched respectively by Charon and St. Peter.

The case of desire is similar: your travel between possible worlds is embedded in the essence of desire. This is what desire is, our feeling and perception of the pull of the better world, our imagination reaching out from here to the place where what is desirable lies. As we know, such a process is isomorphic with what generates our metaphors; it follows that desire generates its own metaphors as long as we pay close attention to the de dicto desire, or the meaning of what we desire. We never desire what we seem to desire. We desire something that is metaphorically specified by its de dicto object, as I tried to show above. However, the most fundamental truth is this: because they follow the rules of metaphor generation, death and desire end up being metaphoric, too. We create them like we create all our metaphors. To put it in the simplest possible manner, all travelling meanings are in the end metaphoric; or, meanings when they travel become metaphors. 